\title{
CHEMICAL INDUSTRY IN CHINA ${ }^{1}$
}

\author{
By William Henry Adolph
}

\author{
Shantung University, Tsinan, China
}

Rapid growth and changes in chemical industry in the United States in the last few years have been paralleled by developments of a similar magnitude in China and the other countries of the Orient which were only indirectly touched by the world war. The entire country has reacted rapidly to a number of stimuli, and has presented on the one hand a phenomenal growth in existing industries, and on the other hand a revelation of still more striking latent industrial possibilities. These stimuli have been partly the competition aroused by the aggression of other nationals in the country, and partly of a political nature connected with the prominence given the Shantung question at the peace conference.

Economic engineers have for some time projected industrial enterprise as a solution to relieve the effects of the tremendous population pressure in China. China has been essentially an agricultural country. The last two or three years have seen an enormous step in the direction of her industrial independence. The mysterious Orient is a thing of the past. During the space of a five years' residence in Shantung, the writer has made a number of notes which a certain professional duty seems to suggest should be passed on.

The developments in Shantung are typical of China as a whole. Shantung silk and peanuts have already immortalized the province. The Shantung silk, called pongee on the market, owes its peculiar qualities to the fact that the silk worms are fed on oak leaves, not on mulberry. Shantung hides and oils are rapidly coming to the fore. The causes which have held back these and other industries are twofold: one, a certain lack of trained technical experience on the part of the Chinese operators; the other, the failure on the part of foreign manufacturers of machinery-this trait is largely true of Americans-to study sympathetically the peculiar needs of the Chinese industry, and to design and adapt plant and machinery to the requirements of a less completely organized industry. America, not Japan, strangely enough, has replaced Germany in the affections of the Chinese industrialist. But we in the United States have not risen to our opportunity.

America may well take a lesson from Germany's methods in stimulating chemical industry in Shantung. Her expert studied the industrial needs of the province, designed machinery and plant of a type which was not used in Germany but which was needed in China. Our. America houses too often have sent their catalogs and given up in despair when an order was not received by return mail. But the Germans cultivated the market, then patiently waited, taught, established industrial schools, were patient again, and built themselves into the good graces of the people. Even now the field is still a virgin field, and it requires expensive and rather tender cultivation on the part of the industrialist and commercial : man. An enterprising peanut-oil producer knows perhaps how to run an oil press, but is unable often without help to order the machine he needs from the confusing specifications of an American catalog, and to instal it.

Americans traveling in China are astonished at the extent to which intelligent Chinese are looking to America as the source of new inspiration and help. In traveling through China, the writer found the simple statement that he was an American the most powerful password that could have been given. $\mathrm{He}$ was still more interested in observing the care with which his Chinese associate on industrial trips

1 Received Septemter 6, 1921, mentioned that the foreign visitor was an American. It invariably meant the doors were thrown open with a willingness. This was in spite of the fact that the Chinese manufacturer has preserved a good bit of his medieval reticence, and is cautious about imparting family trade secrets.

The situation in China divides itself into the recognition of two kinds of industries, with two kinds of industrial problems. In the first place are the old Chinese chemical industries, dyeing, glass, paper, etc., which had their origin in China's prehistoric days. In the second place are the chemical industries which are new to China, sulfuric acid, soda, tanning, which are now looked upon as the foundation stones of a modern chemical industry. It is these which have now to be founded from the very beginning.

The first, the old industries, will help fill some of the pages of our history of chemical industry, and will furnish some of the curious illustrations of how practice can race away from theory till theory is lost thousands of years behind. In China these were all small-scale industries, many of them family industries, and in most cases only supplementary to various phases of agriculture. They require a development that will enable them to retain their important position in the economic fabric of the country, and at the same time to satisfy the requirements of modern efficiency. The second, the new industries, involve serious financial problems as well as technical ones.

\section{The Made-In-China Movement}

The "made-in-China" ory which accompanied the recent patriotic movement has taken a real place in the life of the country, and it has not turned out to be but a fleeting enthusiasm. High-school graduates, and ex-soldiers whose experience has been limited to the manufacture of sodawater and vending of opium pills, have set up as chemical manufacturers, and the desire to make, instead of import, will gradually affect the status of our commercial relationship with China.

News came to us recently of a newly founded sulfuric acid plant in central Shantung, where pyrite was plentiful and fuel cheap; they were reported to be in difficulty. On arrival, our surprise was exceeded only by a certain amount of pathetic admiration. A couple of thousand dollars, all the money the investors possessed, had been expended in the erection of a small plant for the manufacture of sulfuric acid by the chamber process. There were four little lead chambers in a row, a pyrite burner was located at one end and at the other end was an outlet pipe for the excess gases. The manager, who was a high-school graduate and had studied a half year of chemistry in high school, stepped proudly forward, and explained that he had designed the plant unaided and that the completed plant was an exact copy of the diagrammatic sketch which was to be found in his high-school textbook. The plant had failed to produce satisfactory acid. The "company" was profoundly disappointed when shown that there were a number of important details which had been omitted in the crude sketch. This is not an isolated case of patriotic enthusiasm.

The "made-in-China" movement also manifested itself in other ways. A short time ago there was erected a high and imposing chimney, with the elements of a factory attached to its base. In a few days the chimney started 
spurting heavy nitric fumes, and simultaneously with the appearance of the fumes there were scattered broadcast over the Chinese republic handbills announcing the founding of a Chinese company for the manufacture of synthetic dyes in China to replace the imported variety. Patriotic Chinese dyers responded with enthusiasm; the new made-inChina dyes prospered with alacrity. The factory became the center of some interest, but visitors were not encouraged. An investigation showed that there were two doors in the factory. Into the east door were hauled on high singlewheeled barrows cases of imported dyestuffs. On the trip through the factory, the cases were opened, labels removed and changed for made-in-China labels, and the dyes were wheeled out the west door to parade as Chinese product. The yellow smudge which appeared from the stack was kept going constantly while the process of pasting on new labels proceeded.

\section{Resume of Chemical Industries}

It is possible to make only a partial list of the principal industrial items which are of interest to the chemist in China.

ALCOHOL-Very little industrial alcohol is manufactured in China. Alcoholic beverages have been used and prepared by the Chinese for ages. There is, however, a large variety of cheap materials aside from grains and sugar wastes which can be used in an alcohol industry.

BLEACH AND BLEACHING-A growing textile industry is demanding large quantities of bleaching powder and other chemicals which have not been used in the past. The new hair-net industry sends hundreds of pounds of old queues, cut off under the republican régime, to the United States to be bleached and dyed, and then has them shipped back to China for making into hair nets for the American market. The desire on the part of China to compete with foreign manufactured articles of all kinds calls for bleaching of the raw materials. The proper conditions exist for the establishment of an electrolytic bleach industry. No electrolytic industrial processes have yet been founded in China.

CEMENT-A few cement mills have been erected to take advantage of excellent raw materials. The Chinese sources of supply do not, however, fill the increasing demand for this and other building materials. Boshan, the ancient glass center in Shantung, is one of the centers where the cement industry would naturally be-developed. The writer has examined many old structures and ruins of masonry which indicate that excellent concrete was used by the Chinese from very ancient times.

CHEMICAL FERTILIZERS-China is an agricultural country and several thousand years of intensive cultivation have exhausted the soil. Crops are raised only by the regular application of fertilizer. This consists principally of sewage, which is dried and marketed; its preparation forms the foundation of a widespread industry. In the absence of any sewer systems, it has been possible to make almost full return of the nitrogen to the soil. The rapid application of scientific methods to agriculture as well as modern principles of sanitation is beginning to demand the building up of a chemical fertilizer industry.

CHEMICALs. Acids-Pyrite is found in fair abundance in China, but sufficient capital and protection have not yet been united to insure a sound sulfuric acid industry. One large acid works has been in operation successfully for a number of years, and a number of others have been planned. No attempt as yet has been made to manufacture C. P: acids. The lead-chamber process is employed in all cases. Nitric acid is manufactured on a small scale.

Alkalies and Soda-Native soda and potash exist in China, but are failing to meet the heavier demands of modern industry. A number of LeBlanc soda works are being erected and conducted under the guidance of Amerioan trained experts.

Saltpeter-In a country so densely populated as China the accumulations of waste nitrogen in densely inhabited centers is considerable. A quantity of saltpeter is produced annually by scraping off the top surface of the ground in and around the dwellings and stables where this can be done conveniently, particularly in the country districts. The material is treated with wood ashes and extracted, and the potassium nitrate is allowed to crystallize.

Alum, Borax, Glauber's Salt, Green Vitriol, Copperas-A number of these fundamental chemical compounds are found native in China or have been manufactured by crude methods since ancient times.

DYES AND DYEING-China possesses and has used for centuries a large group of vegetable dyes, among them indigo, saffron, and a number of yellows, browns, and blacks. These the Chinese have used only in a very crude way, and some of them have been only partly studied, if at all. The fact that the Chinese have not developed their native dyes in a scientific manner is largely responsible for the present large demand for synthetic dyes from abroad.

Synthetic indigo had efficiently stamped out the native indigo which history indicates had its origin in Shantung, China, many centuries ago. The war revived the industry, which is strong in the north. It remains to be seen how the growing of native indigo, which has been on the increase, will survive under modern scientific management. German trade had done much to kill all of China's native dyes, but the war forced a certain return to the use of native dyes and to a certain extent forced the beginning of a scientific investigation of China's natural wealth in dyestuffs.

EGGS, DRIED ALBUMEN, DRIED EGGS-Chinese eggs are much smaller than American eggs and for that reason, in spite of their cheapness, they have not met with favor as fresh eggs on the American market. The price of eggs in China has risen considerably during the last decade, till they now cost about 5 or 6 cents (U. S. currency) per dozen in the egg-producing districts. The dried egg industry has flourished in China for about ten years. The egg is dried in zinc pans whole, or the yolk and albumen may be dried separately. The U. S. Customs requirement, dating from a few years ago, that the zinc content must be less than 0.1 per cent, almost killed the industry, but it recovered with the introduction of the newer method of spray drying. The lay of Chinese hens in Shantung province is higher than the remainder of China, said to be due to the fact that Shantung chickens are fed soy beans, which contain a high percentage of protein. An opportunity exists for the use in China of this large supply of cheap albumen. Attempts have been made to develop the manufacture of artificial ivory, and similar products.

GLASs-Glass has been manufactured in China from prehistoric times, and in the two or three centers where it has been carried on essentially the same methods as were employed in ancient days are now used. Window glass is also manufactured, and improvements are gradually being introduced. One of the first constructive steps furthered by the Germans in Shantung was the establishment of a large glass works. They employed a large staff of Belgian experts to train the Chinese workmen. This particular works was closed in 1914.

MATches-The Chinese were quick to see the advantage of matches over flint and steel, and one of the first of the smaller modern industries to flourish was the manufacture of matches. The white phosphorus and other chemicals re- 
quired are imported, and sometimes the wooden sticks and boxes also, the only cheap materials being the labor involved. The imported phosphorus is in turn derived from bones originally exported from China.

METALS AND MINERALS-It was the reports of China's fabulous mineral wealth which first drew the attention of the Occident, and it is the mining industry which is seeing the gradual disappearance of traditional unscientific methods. The old method of developing mines in China is well illustrated by the story of the founding of the Hanyang Iron Works. The machinery and equipment for this were ordered by an enterprising old viceroy, who knew neither where he was going to locate the plant nor the kind of ore it was to handle, for the ore had not yet been discovered. When he ordered the outfit he was stationed in Canton, in south China; when the machinery arrived, he had been transferred to central China. It was a piece of remarkable good fortune that ore suitable for the type of plant which he had ordered was soon found at his new post, Hankow, and that a coal mine to furnish fuel for running the plant was found nearby.

The mining industry of China for many years was largely a contest between enterprise and the desire of officialdom to share in the profits. Actual prejudice and superstition were not such important factors as often imagined; but successful mining has depended upon the clever manipulation of legal as well as other kinds of machinery.

All the common metals and minerals are found in China, with the exception of any appreciable quantities of gold or petroleum. The mineral wealth of Shantung was largely responsible for Germany's decision to make that her sphere of influence. Those which have drawn considerable attention during recent years are:

Coal-The coal reserves of China half a century ago were estimated to be limitless. Saner surveys now place the figure at about the same as that for the United States; moreover the coal is found in every province, not simply in favored areas. The annual output is at present about one-thirtieth of that in this country. Shantung province does not possess as much coal as it did in Germany's dreams. There are very large deposits of anthracite in China as well as all other varieties. China has just entered upon the role of coal exporter to Europe. The production for 1920 totaled 13,000,000 tons, of which over one-half was anthracite.

Iron-The glowing reports of von Richthofen, Germany's early scientific emissary to China, which told of unlimited reserves of iron ore have also been shown by careful studies to be-erroneous. The presentestimates place the workable iron reserves at $400,000,000$ tons. The production of iron per capita in China is only one-three hundredth of that in the United States.

Antimony and Tungsten-China furnished the world with antimony and the production was stimulated tremendously by the war. Tungsten ore was likewise developed, but the rise in exchange and the attempt of official interests to tax the profits killed this industry and seriously crippled the antimony trade.

PAPER-Hand-made paper has been in use for centuries. The paper, however, is of inferior grade, and does not seem to have shown any improvement during the course of the centuries. Only one modern paper-mill complete with calender machines exists, and this uses old rags as the sole raw material, of which there is an abundant supply in China. The product of this mill has difficulty in competing with imported paper, but the difficulty probably lies, like many other Chinese industrial difficulties, in inefficient management. The future of the paper industry seems to depend upon the discovery of a new Chinese raw material. This is bound up with the fuel question, for all grass and weeds are at present used for domestic fuel and heating; wood, except the bamboos of the south, is too expensive or nonexistent.

POTTERY-China has excelled in the production of glazed ware and porcelain, but the industry still remains on much the same basis on which it has rested for many centuries. The country possesses excellent raw materials, and a number of recent attempts have been made to produce fine heatresistant porcelain for modern laboratory use, but without marked success.

SALT-The production of salt has long been a government monopoly, and the salt tax is one of the government's principal sources of income. The high duty has hindered the development of industries using salt as a raw material. Salt is mined, and brine, both from wells and sea water, is evaporated by solar evaporation. The ancient salt wells of western China, many of them 2500 to 2800 feet deep, are one of the industrial curiosities of the Far East. Use is even made of the salt bittern or mother liquor, which is sold for use as a coagulant in the manufacture of vegetable cheese.

sOAP-In many places in interior China, the Chinese have used varieties of vegetable soap. This is derived usually from a soap bean and contains principles identical with or similar to saponin. The manufacture of soap sprang up all over China with the introduction of the principles of modern chemical industry, and American and European imported soaps are now meeting serious competition. Crude methods are in many places still employed and the products placed on the market are often of doubtful value. There is need for an experienced and well-trained personnel in developing this industry.

SOY BEANS-The soy bean of north China not only is the source of the bean oil which is now the leading article of China's exports, but is the source of numerous other products. The press cake is being used for fertilizer on the rice fields of Japan and seems to meet a special need there which cannot easily be replaced by other varieties of fertilizer. The only serious question to China is that it means the annual shipping out of the country of large amounts of protein material which China should have for use at home. A movement is on foot to make use of the casein which can be prepared from the soy bean and to turn it. into a product like the American bakelite.

sUGAR-The cane-sugar industry has been long established in south China, and the beet-sugar industry has just recently been established in Manchuria and Shantung. Considerable progress remains to be made in the methods for refining the finished product.

TANNING-Cattle raising and the production of hides is a growing industry in north China and Mongolia. The old method for curing leather was not tanning at all. The word "American leather" during the last decade had come to be synonymous with the word for good leather, and the new move to establish home industries included the demand that China's hides must be tanned at home. This is far from being accomplished, but rapid progress is being made. Chrome leather is now produced successfully, and the other processes are gradually being put into operation. The need is for trained and experienced leather men.

VEGETABLE OILs-The oil industry in China includes: castor oil, cottonseed oil, peanut oil, sesamum oil, soy-bean oil, tung oil (China wood oil). These oils have long been produced and fill certain domestic needs. The progress of the last few years has meant little else than the extensive substitution of modern machine presses for the old-time crude and clumsy wedge devices for squeezing the seeds till a fair amount of the oil was expressed out. Practically no study has been made in China of the refining and proper 
standardization of these oils for the industries. Many of the oils will ultimately be worked up into their various products with profit before being exported. No paint industry has yet been developed. All good paint is imported, though all the necessary raw materials exist in the country for a prosperous industry. The Chinese have been satisfied in the past with a few kinds of good but extremely expensive lacquer, and with poor types of varnishes and paints made from oils which at best were only semi-drying oils. The improvement of the tung-oil industry starts with the growth, selection, and improvement of the tung tree.

\section{CoNCLUSION}

The writer is anxious to urge that the chemical industries of China need our sympathetic interest in their development, and also a goodly amount of American capital. The industrial situation is characterized by cheap labor, and by a surprising manual skill and power of application on the part of the Chinese workman.

1. This open door is an industrial one; it is not merely a political phrase. In spite of ourselves, American interests are being dragged into the China field. American locomotives in increasing numbers are appearing on the Chinese railways. It is significant that not we, but our Americantrained Chinese students, are putting them there.

One is impressed by the fact that the discuissions of industrial problems which appear in the journals of this country are so easily limited to the boundaries of the United States; on very special occasions they may be extended as far as Alaska or the Philippines. Astounding revelations of the ignorance of technical men in the United States upon the needs and problems of the industrial world abroad crop up. A few years ago an American consulting engineer who pretended to cater to the oriental field and who was anxious to keep us in China supplied with all the catalogs and literature on the latest types of machinery, sent a supply of pamphlets expounding the virtues of a new device which was just appearing on the market-a stump-puller. His machine might have been used in clearing the primeval forests of central Africa, but Shantung had been for so many treeless centuries in the grip of floods and famines, with mountains bare and every inch of soil under such intensive cultivation, that we could have desired nothing so much as a single stump to pull. There are frequent evidences of our lack of information on the geography of the districts abroad which we plan to serve in a technical capacity. September 6 to 10,1921 .

\section{Factors Influencing the Vitamine Content of Foods}

\section{By R. Adams Dutcher}

Department of Agricultural Chemistry, Pennsylyanza State Coliege, State College, Pa.

Probably no phase of the vitamine question is attracting greater attention at the present time than that which has to do with the vitamine content of our natural and prepared foods and feeding materials. Hardly a week passes that the writer does not receive letters from teachers, housewives, dairy-men, and manufacturers, asking for advice regarding the effect of this or that process of food treatment upon the vitamine content of the particular article of diet in which they are interested. It is difficult, if not impossible, to answer many of these questions satisfactorily for the reason that many of the problems have not been investigated and many of those which have received attention have been influenced by so many factors that it is difficult to say with any degree of certainty what the real facts may. be.

In a paper of this type it is impossible to do more than point out what seem to the writer to be some of the outstanding phases and to emphasize some of those factors which seem to be of the greatest importance.

\section{Foods of Plant Origin}

It is quite clear that fresh undried cereals possess antineuritic and antiscorbutic properties that are not manifest in the dried seed. While the antineuritic vitamine occurs more or less abundantly in the dried cereals, it is found that the antiscorbutic vitamine has practically disappeared during the drying process.

When seeds are allowed to germinate, ${ }^{1, *}$ however, it is found that they possess marked antiscorbutic potency and their value with regard to the antineuritic vitamine has been enhanced to some extent. The British military authorities ${ }^{2}$ have made use of this fact by requiring the use of sprouted

* Numbers in text refer to Bibliography, p. 1104. beans as an antiscorbutic food for certain of their expeditionary forces.

Steenbock ${ }^{3}$ argues that most plant tissues, which are characterized by the production of carotinoid pigments, are relatively rich in the fat-soluble vitamine. $\mathrm{He}$ is of the opinion that these pigments are very closely related to the fatsoluble vitamine or are identical with it. Palmer, ${ }^{4}$ Drummond and Coward, ${ }^{5}$ and Stephenson ${ }^{6}$ do not hold this view and cite experimental evidence to disprove Steenbock's generalization.

The relationship between metabolic processes in the plant and the production of fat-soluble vitamine is not at all clear, and the fact that plant leaves are rich in this accessory factor has caused considerable speculation. Some writers maintain that the vitamine is a result of or associated with metabolic processes. This is supported by the fact that the vitamine content of plants such as the carrot ${ }^{7}$ and alfalfa ${ }^{8}$ seems to be at its maximum during the early stages of growth, when the plants are young and when metabolic processes are most active.

It must be of considerable satisfaction to the botanist to know that the animal kingdom is dependent upon the plant world for vitamines as well as the other nutrient materials. It appears to be quite evident that the animal body cannot synthesize vitamines, at least to an extent where they can be considered of dietary importance.

\section{Foods of Antmal Origin}

There are undoubtedly four factors operating to influence the vitamine content of fleshy foods: (a) The diet of the animal previous to slaughtering, (b) the type or species of animal, $(c)$ the type of tissue used as food, and $(d)$ the method of food treatment.

With reference to the first factor, $i$. e., the diet of the animal, the evidence points to the fact that the vitamine content of body tissues must, of necessity, be influenced by the vitamine content of the diet. Drummond and his coworkers ${ }^{9}$ have shown that lard does not usually contain the fat-soluble vitamine, owing to the fact that the ration of the 